International Journal of Engineering \& Technology, $7(3.6)(2018) 438-440$
International Journal of Engineering \& Technology
WPC
Website $:$ www.sciencepubco.com/index.php/IJET
Research paper

\title{
Advancement of E-Book Through Automation System in Department of Islamic Education (STAI) Miftahul Ula Nganjuk
}

\author{
Muh Barid Nizarudin Wajdi ${ }^{1 *}$, Paisal Halim², Syamsiah Badruddin ${ }^{2}$, Hartono ${ }^{2}$, Hasim A. Abdullah ${ }^{2}$, \\ Muhammad Ikhsan Setiawan ${ }^{3}$, Ifit Novita Sari ${ }^{4}$, Diah Puji Nali Brata ${ }^{5}$, Janner Simarmata ${ }^{6}$

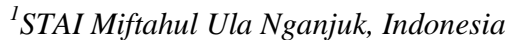 \\ ${ }^{2}$ Institut Ilmu Sosial dan Manajemen STIAMI, Jakarta, Indonesia \\ ${ }^{3}$ Department of Civil Engineering, Narotama University, Surabaya, Indonesia \\ ${ }^{4}$ University of Kanjuruhan Malang, Indonesia \\ ${ }^{5}$ STKIP PGRI Jombang, Indonesia \\ ${ }^{6}$ Universitas Negeri Medan, Indonesia \\ * E-mail: baridnizar84@ gmail.com
}

\begin{abstract}
Improving quality of learning related to the management of supporting facilities in the learning process cannot be separated from the library facilities implemented by the librarian. It is essential to ensure that the learning activities can be done well. Therefore the librarian is asked to design a system called Library Automation. Instructional design in E-Book development methodology with this library Automation system uses library to study and field study using observation and interview. This system is made to accelerate the typical daily activities. The application of automation gives a great advantage; the students can be able to find the information quickly. Furthermore, this automation system is already based on Online. The existence of the e-book gives the significant benefits in STAI Miftahul Ula Nganjuk. In expanding perusing interest, the presence of the digital book can likewise enhance the administrations institutionally, takes care of its requests advancement, improves the execution, and keeps up a realness of an archive. The understudies are exceptionally happy with this framework. They generally get the data about the books despite the fact that they are not on grounds condition.
\end{abstract}

Keywords: E-Book; Automation; Online.

\section{Introduction}

The improvement of science and innovation has affected all fields, including the library. A library which is a storage facility of data uses change in introducing and looking for data[1]. Additionally, the improvement of science and innovation can likewise keep up the validness of the data. Data isn't just in printed frame yet also as electronic/advanced or frequently called digital book. the Digita book is a sort of book in electronic shape; its reality is regularly scattered and sold on the web. It has a few points of interest that are not found in physical books.

Library Unit gets the large effect from science and innovation, different structures and techniques connected in the utilization of science and innovation to look for data. Hence, STAI Miftahul Ula Nganjuk builds up the E-Book by utilizing this library robotization framework. This is done to encourage getting to the books of nursing. the Digital book is being created at the Libraries of STAI Miftahul Ula Nganjuk. Its fabricate is intended to expand perusing enthusiasm of library clients, particular academicians of STAI Miftahul Ula Nganjuk.

The purpose of the library automation STAI Miftahul Ula Nganjuk is to improve services, to accelerate and minimize the work, to provide flexibility to access information, to meet the demands of IT development, to improve the performance, to disseminate information both within and outside the institution (In- ternet). One of the benefits of Library Automation STAI Miftahul Ula Nganjuk is to facilitate the search through the catalog. Libraries that use directories automation program manually, users can access through three approaches, namely the title, the author, and the subject.

Library Automation allows users to search information, particular catalogs through OPAC (Online Public Access Catalog). Users can search for a book title simultaneously, and they can search for books with various approaches[2]-[5]. For example through the title, the title keyword; author, the author keyword; subject, the subject keywords and other subjects as needed. By using automation, the librarian's work more quickly because users can serve themselves in the process of borrowing and returning, extension, and searching for library materials. Librarians can do other job, for example, indexing. By using automation process can also save costs such as the costs of paper and labor costs can be replaced by the computer technician. The services at the library are easier to use, and librarians can do other activities to improve the facilities. Library Automation facilitates in making statistical reports. The reports can be created with the data that already exists by using automated processes that can automatically enter into statistics. Library Automation can be used for accreditation. The school's accreditation needs assessment of the quality of the library so that the library needs to be automated[6]. 


\section{Theoretical Review}

The system is "a network of procedures that are interconnected, gathered together to perform an activity or to accomplish a particular goal." The system approach which is a network of procedures emphasizes the sequence of operations within the system. While, the system approach emphasizes the component or element, according to Gordon B. Davis "A system is a group of elements or parts which are interconnected or integrated with the same purpose to achieve a particular goal[7]. While Raymond McLeod defines the system as a group of elements that are integrated with the same purpose to achieve a goal[8].

Based on the opinions above, it can be concluded that a system generally has several components, each of these components works together to achieve a goal. Based on the definition of the system, the system has the elements or components that support it, namely:

\subsection{Input}

Input is energy or raw materials put into the system.

\subsection{Process}

A system has a processing section that will change inputs into outputs.

\subsection{The Output is the Result of Energy Or Raw Mate- rials That Can be Used by Others and Classified Into Useful Production. Output Can be an Input for Other Sub-Systems.}

\subsection{Feedback}

Is a condition that occurs towards the system resulted from the implementation of the system. This feedback may favor or interfere with the survival of the system. The assessment of the system's success is determined by this process.

\subsection{Mechanism of Control}

The activities that focus on controlling the work implement in the process to achieve the system.

\subsection{Restrictions}

Is an area that limits a system with other systems or with the external environment.

\subsection{Objectives of the System}

A system can have a goal or purpose. If a system does not have a target, the operating system will be useless. The goal of the system will determine the necessary input and the resulted output. A method is successful when it achieves the goals or objectives.

\section{Method}

\subsection{Instructional Design}

This stage is divided into two groups, library and field studies Library study is an activity related to the assessment of the sources of reference for getting theoretical, conceptual and practical basis about the problems of the research. This library study is conducted by obtaining the data from the literature in the form of books, journals.

Field study is conducted through the collection of data relating to information systems problems existing in the field. This activity is a stage that aims to explore the required data relating to the issues under discussion. These data include the facts about the library data, SOP in libraries, data processing, business process models or running work system, the application, and utilization of the information systems on a running system and standardization of the information systems on a running system and standardization of the work system that has been enacted.

\subsection{Design Development}

The results of the library and field studies are summarized as a basis of thinking and is associated with the methodology to be done, so it will get a development solution of library automation system which is suitable with STAI Miftahul Ula Nganjuk.

Table 1: Development solution of library automation system

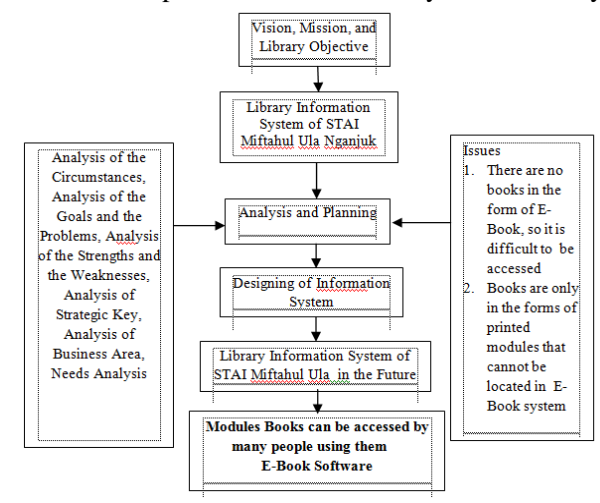

\section{Result and Discussion}

Along with the advances in science and technology today, the library of STAI Miftahul Ula Nganjuk has referred to the services in digital form. Some of the existing collection has been made into a digital form. This is done to meet the needs of users, particularly to increase the reading interest of the library users.

According to Wikipedia, e-book (electronic book, or e-book) which is known as digital books, is e-text in the form of digital media and sometimes protected by digital copyright. The shapes can be pdf, word, HTML, text, etc. But, the popular form is usually pdf file that can be read by the programs like acrobat reader which can be downloaded from the internet. E-book in STAI Miftahul Ula Nganjuk is not only in the form of pdf files, but it is processed again by the system/software. E-book in the library of STAI Miftahul Ula Nganjuk gives the significant impact on the reading interest of the students. Most of the students state they are satisfied to use it.

In making the e-book, there are some points to note:

\subsection{Arrange the Layout Well and Consistently}

If you write an e-book that has some points and each point has sub-points, then make sure that the format of writing at that point consistently between the points and sub-points. The consistency of your writing makes your digital books more professional and exciting.

\subsection{Useav Attractive Font for Digital Books}

Font usage on digital books should use a font that is commonly used. It is to make the library users feel comfortable, especially users of digital books. As for the standard font is Times New Roman.

\subsection{The Combination of Animation and Colors Used}

In making the e-book, use the exciting designs, so that the users feel comfortable in reading it. This design can be inherited from the system and can also be used on election animation. The attrac- 
tiveness of the e-book depends on the creativity of the designer. So that we need to read and study the various sources concerning about this e-book. These sources are mostly obtained from the internet.

Making e-book is the target of Librarian of STAI MIftahul Ula Nganjuk. Nowadays, there are already some of the collections that have been made into an e-book. All are designed with a variety of shapes. There is a default application, and there is also the creativity of librarian. The designs can be seen in the figure below:
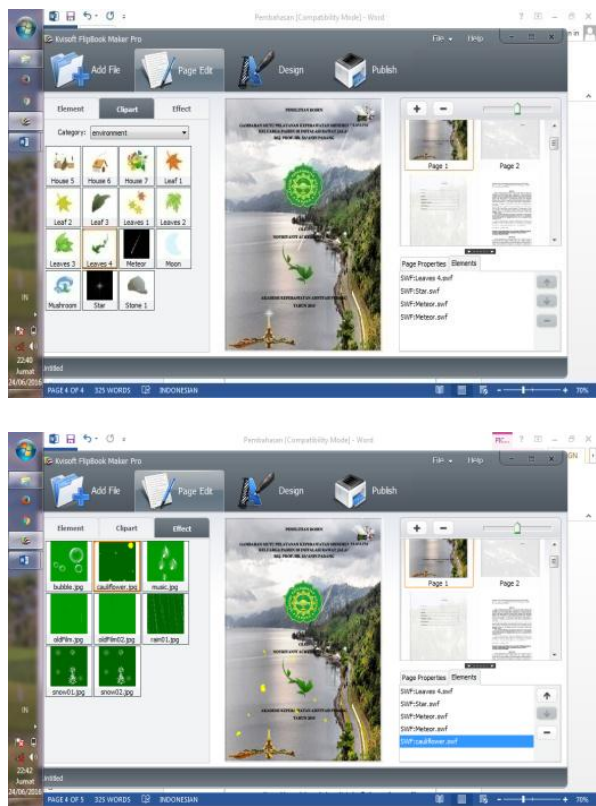

Fig. 1: The designs of Librarian E-book

\section{Conclusion}

Advances in technology bring library of STAI Miftahul Ula Nganjuk leads up to services in digital form. Some of the existing collection has been made into a digital form to meet the needs of users and increase the reading interest of library users.

Information technology makes a variety of changes in the library, the library that usually only stores information in the form of books also provided information in electronic form/digital (e-book) now. This information is essential to increase reading interest. An e-book should be designed as well as possible in order the users feel satisfied and happy to use it.

\section{References}

[1] C. C. Kuhlthau, Seeking meaning: A process approach to library and information services. Libraries Unltd Incorporated, 2004.

[2] C. A. Hert, "User goals on an online public access catalog," J. Am. Soc. Inf. Sci., vol. 47, no. 7, pp. 504-518, 1996.

[3] C. R. Hildreth, "Online public access catalogues," in Essen Symposium, 1985, pp. 1-55.

[4] M. M. Yee and S. S. Layne, Improving online public access catalogs. American Library Association, 1998.

[5] P. Gavin, "OPAC: online public access catalogue," in New Information Technologies and Libraries, Springer, 1985, pp. 121-126.

[6] S. Herman, "Manajemen Sumber Daya Manusia," Yogyakarta Graha Ilmu, 2008.

[7] G. B. Davis and M. H. Olson, Management information systems: conceptual foundations, structure, and development. McGraw-Hill, Inc., 1984.

[8] R. McLeod and G. Schell, Sistem informasi manajemen. Indeks, 2004. 